\title{
INTEGRATION OF SOFT SKILLS OF GRADUATES OF THE TECHNICAL UNIVERSITY IN ZVOLEN AND THEIR APPLICABILITY IN SLOVAK BUSINESS ENVIRONMENT - THE CASE STUDY
}

\section{Gejdoš, P., Simanová, L'., Čierna, H., Sujová, E., Schmidtová, J.}

Pavol Gejdoš / Technical University in Zvolen, Faculty of Wood Sciences and Technology, Department of Economics, Management and Business, T.G. Masaryk 24, 96001 Zvolen, Slovak Republic. Email: gejdosp@tuzvo.sk.

L'ubica Simanová / Technical University in Zvolen, Faculty of Wood Sciences and Technology, Department of Economics, Management and Business, T.G. Masaryk 24, 96001 Zvolen, Slovak Republic.Email:simanova@tuzvo.sk.

Helena Čierna / Technical University in Zvolen, Faculty of Technology, Department of Manufacturing Technology and Quality Management, Študentská 26, 96001 Zvolen, Slovak Republic. Email:cierna@tuzvo.sk.

Erika Sujová / Technical University in Zvolen, Faculty of Technology, Department of Manufacturing Technology and Quality Management, Študentská 26, 96001 Zvolen, Slovak Republic. Email: erika.sujova@tuzvo.sk.

Jarmila Schmidtová / Technical University in Zvolen, Faculty of Wood Sciences and Technology, Department of Mathematics and Descriptive Geometry T.G. Masaryk 24, 96001 Zvolen, Slovak Republic. Email: jarmila.schmidtova@tuzvo.sk.

\section{Abstract}

Higher education institutions annually produce hundreds to thousands of graduates with the same or similar education. The new graduates only with academic background compete with the graduates from previous years who have acquired some practical experience. The individual will only assert themselves through the complex of superstructure competencies and the ability to apply them effectively and practically for the benefit of the employer. The paper aims to present research focused on the analysis of soft skills and summarising the requirements for the soft skills competencies of the graduates from the Technical University in Zvolen in terms of employers' expectations in the Slovak republic. The research was carried out in the form of a questionnaire survey, and the results of the questionnaire survey were evaluated by the method of mathematical-statistical analysis by non-parametric testing of significance. On the basis of the testing of significance, the hypothesis for specific areas of soft skills competencies was confirmed, suggesting that students' competencies in these areas do not reach the level demanded by enterprises, and therefore, it is necessary to improve the quality of education in that area to match students' real knowledge with business requirements.

Implications for Central European audience: The global labour market requires the introduction of new competencies so that university graduates can work in a domestic or transnational context. An advantage is the added value showed by various interpersonal skills represented by soft skills. In the research, we focused on the analysis and summarising the 
requirements for the soft skills. Based on the testing of significance, the hypothesis of the statistical significance of the difference for specific areas of soft skills competencies was confirmed, suggesting that students' competencies in these areas do not reach the level demanded by enterprises. Soft skills and emotional behaviours deficits could affect business outcomes.

Keywords: soft skills; higher education; business environment; competencies JEL Classification: I23, J24

\section{Introduction}

Research and the facts in the area show that soft skills have an important role in determining a person's success in work. Robles (2012) and Levasseur (2013) state that hard skills focus on traditional technical expertise such as computational skills and technical problem-solving, while soft skills are a combination of social and interpersonal skills, personal qualities and career attributes. A hard skill is a minimum requirement for a person to enter certain occupations, while a soft skill will determine development in the job. It is, therefore, the education, including a vocational challenge to integrate both kinds of components in an integrated manner and not a biased one, that is able to prepare complete human resources can work and grow in the future (Sharma, 2009). Engineering education is critical for sustainability, given the key role that engineers have in shaping the development of society (Vehmaa et al., 2018). Soft skills as non-technical skills that are intangible but extremely demanded (O’Brien, 2001). According to Murti (2014), soft skills are communication, conflict resolution, interpersonal relationships, presentation, negotiation, team building and other characteristics defined in terms of expected results and not methods or techniques. Weiner (2000) classified soft skills into two: intrapersonal skills and interpersonal skills. Intrapersonal skills refer to an individual's ability in managing themself for optimally developing works, for example, time management, stress management and creative thinking. Meanwhile, interpersonal skills are defined as skills of an individual in managing their relationship with others for optimal professional development, i.e. ability to motivate, to lead and to negotiate. The labour market needs more specific technical skills ever, but it is also increasingly becoming in need of other types of skills, such as teamwork, assertiveness, and the ability to work under pressure (De Villiers, 2010). We have stated only a few definitions of soft skills that can be summarised as non-technical, interpersonal and socially important behavioural competencies that relate to social or emotional intelligence (EQ) and overlap with each other and have a significant impact on recruitment. Educational institutions are often criticised because their graduates do not have sufficient soft skills, whether it is creative thinking, teamwork, stress resilience, organisational skills or the ability to resolve conflicts. The priority of educational activities in the field of technical education should be, in addition to vocational education, also equipping students with competencies on how to solve technical problems with creative methods. Wu and Wu (2020) add that modern technical education should also address the design of creativity courses that support students' creativity, critical thinking and the transfer of learning skills. Baer and Kaufman (2019) state that education in the field of creativity tends to adopt different interpretations and perspectives to define students' creative competence and their dependence on the relevant field or discipline and the opinions of 
experts. Some authors argue that creativity primarily means thinking competencies, others argue that creativity requires different thinking, and some even considered creativity to be an exercise in the imagination. Definitions of creativity are different, but most of them follow the standard bipartite definition given by Runco and Jaeger (2012), stating that creativity includes originality (novelty, uniqueness, newness) and efficiency (value, appropriateness) by Eteläpelto and Lahti (2008), Gajda et al. (2017), Walsh et al. (2017). Originality in itself may result in unnecessary products or ideas and, conversely, effective products or ideas may not in themselves contribute to new understanding or knowledge. Globally, Sullivan (2017) identified three main approaches of theories of creativity since the mid-20th century: the cognitive-psychological approach, the socio-psychological and the socio-cultural approach. Park et al. (2017) report that diversity of knowledge creates synergies between different types of knowledge by strengthening the link that ultimately leads to improved innovation and performance. Based on the vast diversity of theoretical perspectives, there is no generally accepted definition of creativity. However, there is general agreement that creativity is better understood as a holistic, multidimensional concept (Sarsani, 2005). Within the psychological tradition, the standard definition of creativity includes two components: originality and usefulness (Runco \& Jaeger, 2012). In addition to these components, scientists such as Kaufman and Sternberg (2007) and Simonton (2012) have proposed quality as the third component of creativity. The findings of Andiliou and Murphy (2010), Bereczki and Kárpáti (2018) and Mullet et al. (2016) suggest that teachers value creativity and believe that everyone can be creative to some extent and that creativity can be developed in schools. Bereczki and Kárpáti (2018) also identified factors limiting creativity in the learning environment, including factors at the context level (e.g. overloaded curricula, standardised tests), teacher level (e.g. lack of freedom, traditional approaches to teaching), student level (e.g. individual differences between students, lack of involvement) and level of parents (e.g. negative attitude and insufficient support).

Understanding the impact of teamwork on performance is important because teamwork is viewed by some researchers as one of the key driving force for improving a firm's performance. Team members enhance their skills, knowledge and abilities while working in a team (Froebel \& Marchington, 2005). Researchers and experts indicate that effective behaviours and concepts related to teamwork can increase the level of improvement of employees" performance and their productivity as well as enhancing the ability to solve conflicts and facing urgent and sudden challenges at work. According to Mulika (2010), teamwork can be accurately defined as a group of individuals who work cooperatively to achieve a specific task or goal. This skill has become appreciated that so much that large organisations have designed special tests to determine the abilities of their employees to work on teams. Therefore, teamwork ability became an essential skill that every worker must have to be accepted in the job. Teamwork is a precise organisational measure that shows many different features in all types of organisations, including non-profit. Conti and Kleiner (2003) reported that teams offer greater participation, challenges and feelings of accomplishment. Tarricone and Luca (2002), in their case study on successful teamwork, defined successful teamwork as synergism existing between all team members creating an environment where they are all willing to contribute and participate in promoting and nurturing a positive, effective team environment. Organisational skills are a set of techniques used by an individual to facilitate the efficiency of future-oriented learning, problem-solving, and task completion. The organisation requires the integration of several elements to reach a planned 
goal. Dawson and Guare (2010) define organisation skills as the ability to design and maintain systems for keeping track of information or materials. The broader domain of executive functioning plays a large role in the development and execution of organisational skills. The fact is that organisational skills are a prerequisite for success and that those skills must be taught to children (Fry, 2005; Gambill et al., 2008). It is these skills that help students become successful in school and continue to be successful in the working world (Fry, 2005). Another important soft skill refers to problem-solving, which is dealing with a questionable, unresolved or difficult question or task. The following steps lead to solving such situations: problem definition, problem analysis, production of different problem alternatives, evaluation and selection of the most suitable alternative, implementation of decisions and monitoring and evaluation. Therefore, it is necessary to see the problems in the context, identify their causes, identify solutions and verify that the solution was correct. Collaboration within different departments of a single company tends to be full of situations where there is a conflict of views and interests, and there are often different conflicts that need to be resolved as effectively as possible for the good of the company. However, conflicts can also be seen as a dialogue where new ideas, perspectives and solutions arise. Positive conflict resolution implies the ability to concentrate on the problem, propose alternative solutions and, above all, a willingness to compromise (Holečková, 2010; Peters-Kühlinger, 2007).

\section{Methodology of research}

The methodology used to investigate the employment of students of the Technical University in Zvolen was thoroughly described and published in the article "Application of Soft-Skills Competence in Practice (Practice vs Students)" authored by Čierna et al. (2020). The mentioned methodology was divided into a questionnaire survey as a tool to obtain the data from students and enterprises. The data collected from the questionnaires were analysed and evaluated according to Likert's scale and tested by the Shapiro -Wilk (SW) test and the Mann-Whitney U-test.

The following sequence of steps was chosen to carry out the research:

1. Defining the soft skill areas (04-06/2018).

2. Defining the relevant knowledge areas of information-communication technologies (07-09/2018).

3. Questionnaire design. (10/2018).

4. Random choice of respondents and their demographic characteristics specification. $(11-12 / 2018)$.

5. Evaluation of the results of the questionnaire research $(01-03 / 2019)$.

The concept of the questionnaire was based on the definition of relevant areas of soft skills assessment. Respondents evaluated the individual areas through the Likert scale of evaluation, which is shown in Table 1. 
Table 1 | Likert scale of evaluation

\begin{tabular}{cccccc}
\hline Statement & $\begin{array}{c}\text { Excellently } \\
\text { developed }\end{array}$ & $\begin{array}{c}\text { Developed } \\
\text { very well }\end{array}$ & $\begin{array}{c}\text { Developed } \\
\text { well }\end{array}$ & $\begin{array}{c}\text { Developed } \\
\text { sufficiently }\end{array}$ & $\begin{array}{c}\text { Not } \\
\text { developed }\end{array}$ \\
\hline Point value & 1 & 2 & 3 & 4 & 5 \\
\hline
\end{tabular}

Source: own elaboration

The questionnaire for enterprises was sent to 200 employees of enterprises operating in the Slovak Republic. A total of 155 respondents responded to the questionnaire, which corresponds to a $77.5 \%$ return on the questionnaire. An analysis of the respondents found that $35 \%$ of the participating respondents were from large enterprises, $27 \%$ were from medium enterprises, and $38 \%$ of the questionnaires were represented by respondents from small enterprises with less than 50 employees.

A total of 132 questionnaires was distributed among students, of which return was $100 \%$. Regarding the total number of students, the proportion of students studying for a bachelor's degree (Bc.) was $55 \%$, and the proportion of students studying for a master's degree (Ing.) was $45 \%$.

A questionnaire research method was used to analyse the competencies of graduates of technical university studies in which responses were evaluated using the Likert scale. The data obtained from the questionnaires were first tested for normal distribution to select a suitable method of mathematical induction. The Shapiro-Wilk test was chosen from many tests that statistical software currently provides. The assumption that our research outputs are non-parametric variables that do not exhibit a normal distribution was verified. Based on the results of the testing, subsequently, non-parametric testing using statistical induction methods, namely Mann-Whitney's $U$ test, was used to investigate the significance of the difference between the expected and actual state of competencies. One of the most commonly used tests of normality is the Shapiro-Wilk (SW) test. The test is based on determining whether the points of the constructed quantile-quantile graph ( $Q-Q$ plot) differ significantly from the regression line outlined by these points. At the level of significance $\alpha$ selected beforehand, the null hypothesis $\mathrm{H}_{0}$ was tested: $\mathrm{F}(\mathrm{x})=\mathrm{F} 0(\mathrm{x})$ against the alternative hypothesis $H^{1}: F(x) \neq F 0(x)$, where $F$ is the empirical distribution function of the sample of the range at $\mathrm{F} 0$ distribution function of normal distribution norms $(\mu, \sigma)$ with parameters $\mu$ and $\sigma$ unspecified. SW test is mainly used for samples of smaller ranges $n \leq 50$. The ordered values $\mathrm{x}_{(1)}, \mathrm{X}_{(2)} \ldots \mathrm{X}_{(\mathrm{n})}$ of randomly selected sample $\mathrm{x}_{(1)}, \mathrm{X}_{(2)} \ldots \mathrm{x}_{(\mathrm{n})}$ were considered.

The results were presented in tables, radar charts, and box plots.

\section{Results and discussion}

\section{Creative thinking competence evaluation}

Table 2 shows the results from questionnaires using descriptive characteristics - absolute frequency (AP) and relative frequency (RP) for creative thinking (CT) area. Individual assessments are characterised by the Likert scale (LS) for expected states (OS) and actual states (SS). As we can see, the expected state and the actual state are significantly different. 
Table 2 | Descriptive statistics parameters for the area of creative thinking

\begin{tabular}{|c|c|c|c|c|}
\hline \multirow{2}{*}{$\begin{array}{c}\text { Creative } \\
\text { thinking } \\
\text { LS }\end{array}$} & \multicolumn{2}{|c|}{ os } & \multicolumn{2}{|c|}{ SS } \\
\hline & AP & $\mathbf{R P} \%$ & AP & $\mathbf{R P} \%$ \\
\hline 1 & 59 & 38.2 & 14 & 9.2 \\
\hline 2 & 45 & 29.1 & 37 & 23.6 \\
\hline 3 & 17 & 10.9 & 79 & 50.9 \\
\hline 4 & 17 & 10.9 & 22 & 14.5 \\
\hline 5 & 17 & 10.9 & 3 & 1.8 \\
\hline
\end{tabular}

Source: own elaboration

Figure 1 shows the RP of individual ranks of the LS for the area of creative thinking.

Figure 1 | Radar chart of RP for LS ranks for the area of creative thinking by OS and SS

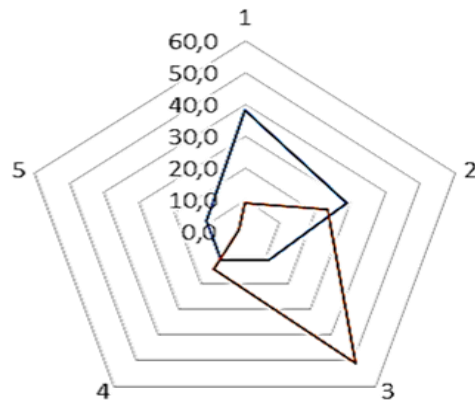

- RP OS - \% RP SS - \%

Source: own elaboration

By comparing the graphs OS and SS, it can be concluded that there are considerable differences between ratings. To confirm the hypothesis about the significance of the difference, the Mann-Whitney $U$ test shall be used to test the results. The test results for the creative thinking area are shown in Table 3.

Table 3 | The Mann-Whitney $\mathrm{U}$ - test results for the area of creative thinking

\begin{tabular}{llllllll}
\hline & $\begin{array}{l}\mathbf{p}<\mathbf{0 . 0 5} \\
\text { Sum } \\
\text { of ranks } \\
\text { CT_OS }\end{array}$ & $\begin{array}{l}\text { Sum } \\
\text { of ranks } \\
\text { CT_SS }\end{array}$ & $\begin{array}{l}\text { Test } \\
\text { criterion } \\
\mathbf{U}-\text { value }\end{array}$ & $\begin{array}{l}\text { Test } \\
\text { criterion } \\
\mathbf{Z}- \\
\text { modified } \\
\text { value }\end{array}$ & $\begin{array}{l}\text { p- } \\
\text { value }\end{array}$ & $\begin{array}{l}\text { N valid } \\
\text { CT_OS }\end{array}$ & $\begin{array}{l}\text { N valid } \\
\text { CT_SS }\end{array}$ \\
\hline $\begin{array}{l}\text { Creative } \\
\text { thinking }\end{array}$ & 2595.50 & 3509.50 & 1055.50 & -2.812 & 0.005 & 155 & 155 \\
\hline
\end{tabular}

Source: own elaboration

Based on the test results and the $p$-value $(p=0.005)$, the null hypothesis is rejected and incline to the alternative hypothesis that there is a statistically significant difference between OS and SS. The box plot shows the results of the respondents' evaluation (Figure 2). 
Figure 2 | Box plot for the variable of creative thinking

Box \& Whisker Plot Variable: Creative thinking

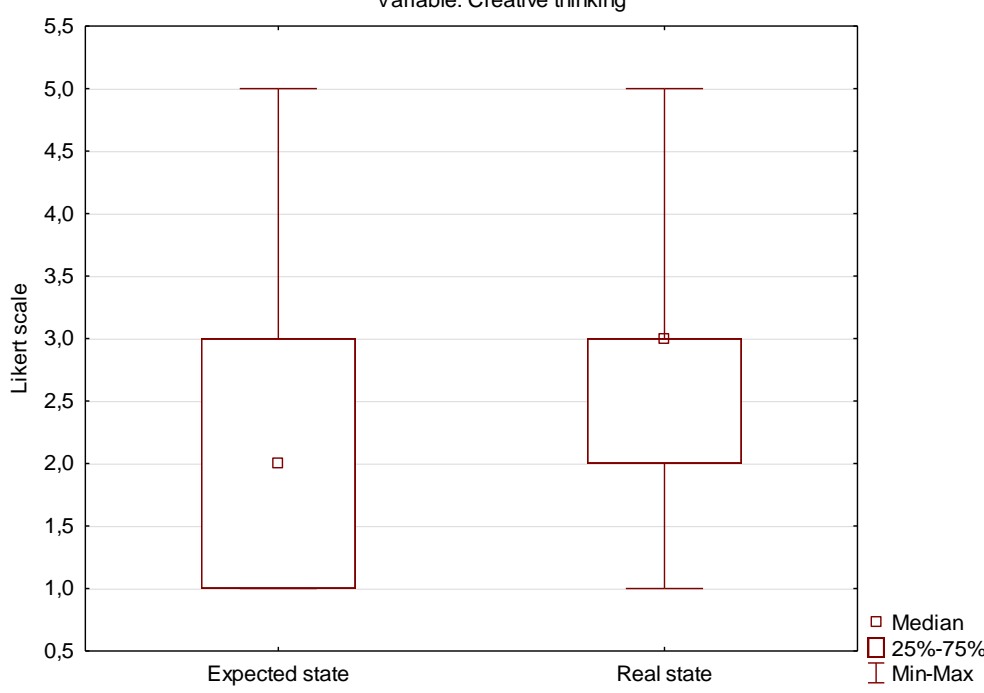

Source: own elaboration

Figure 2 shows:

- 25 to $75 \%$ of all respondents' assessments in the area of creative thinking for the expected state are within 1-3 of Likert scale corresponding to the 2nd and 3rd quartiles;

- $\quad$ the median, i.e. the middle value, for the expected state of creative thinking is 2.0, which corresponds to a very well developed area of soft skills;

- 25 to $75 \%$ of all respondents' assessments in the area of creative thinking for the actual state are within 2-3 of Likert scale corresponding to the 2nd and 3rd quartiles;

- $\quad$ the median, i.e. the middle value, for the actual state of creative thinking is 3.0 , which is a well-developed soft skills competence.

\section{Assessment of competencies in the area of teamwork}

Table 4 shows the results from questionnaires AP and RP for the teamwork (TW) area. Individual assessments are characterised by the Likert scale (LS) for expected states (OS) and actual states (SS). As we can see, the expected state and the actual state are not significantly different. 
Table 4 | Descriptive statistics parameters for the area of team work

\begin{tabular}{|c|c|c|c|c|}
\hline \multirow{2}{*}{$\begin{array}{c}\text { Team work } \\
\text { LS }\end{array}$} & \multicolumn{2}{|c|}{ OS } & \multicolumn{2}{|c|}{ SS } \\
\hline & AP & $\mathbf{R P} \%$ & AP & RP \% \\
\hline 1 & 59 & 38.2 & 41 & 26.4 \\
\hline 2 & 37 & 23.6 & 45 & 29.1 \\
\hline 3 & 20 & 12.7 & 28 & 18.2 \\
\hline 4 & 11 & 7.3 & 20 & 12.7 \\
\hline 5 & 28 & 18.2 & 21 & 13.6 \\
\hline Total & 155 & 100 & 155 & 100 \\
\hline
\end{tabular}

Source: own elaboration

Figure 3 shows the RP of individual ranks of the LS for the area of teamwork.

Figure 3 | Radar chart of RP for LS ranks for the area of teamwork by OS and SS

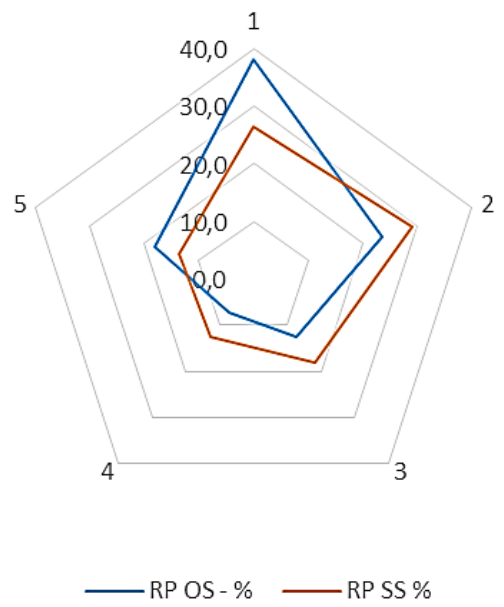

Source: own elaboration

By comparing the graphs OS and SS, it can be concluded that there are no significant differences between the ratings. To confirm the hypothesis about the significance of the difference, the Mann-Whitney $U$ test shall be used to test the results. The results of the test for the teamwork evaluation are shown in Table 5.

Table 5 | Results of Mann-Whitney U-test for the area of teamwork

\begin{tabular}{llllllll}
\hline & $\begin{array}{l}\mathbf{p}<\mathbf{0 . 0 5} \\
\text { Sum } \\
\text { of ranks } \\
\text { TW_OS }\end{array}$ & $\begin{array}{l}\text { Sum } \\
\text { of ranks } \\
\text { TW_SS }\end{array}$ & $\begin{array}{l}\text { Test } \\
\text { criterion } \\
\mathbf{U}-\text { value }\end{array}$ & $\begin{array}{l}\text { Test } \\
\text { criterion } \\
\mathbf{Z}-\end{array}$ & $\begin{array}{l}\mathbf{p}- \\
\text { value } \\
\text { value }\end{array}$ & $\begin{array}{l}\text { N valid } \\
\text { TW_OS }\end{array}$ & $\begin{array}{l}\text { N valid } \\
\text { TW_SS }\end{array}$ \\
\hline $\begin{array}{l}\text { Team } \\
\text { work }\end{array}$ & 2842.00 & 3263.00 & 1302.00 & -1.293 & 0.196 & 155 & 155 \\
\hline
\end{tabular}

Source: own elaboration

The results of the Mann-Whitney U-test for team collaboration did not confirm a significant statistical difference between OS and SS. Based on the results of testing and the corresponding $p$-value $(p=0.196)$, the null hypothesis was confirmed; there is no statistically 
significant difference between the expected and actual states of soft team assessment; i.e. reality and expectations are the same. This result points out that graduates predominantly meet the practice requirements for the skills in that area, and there is no need to improve teaching in that area. As the significant statistical difference between the expected and the actual situation was not confirmed, a box plot showing the distribution of respondent ratings is not provided. Median, i.e. the typical value, for the expected teamwork is 2.0, which means that practice requires highly developed teamwork skills from graduates.

\section{Assessment of competencies in the area of organisational skills}

Table 6 shows the results from questionnaires AP and RP for the organisational skills (OSk) area. Individual assessments are characterised by the Likert scale (LS) for expected states (OS) and actual states (SS). As we can see, the expected state and the actual state are slightly different.

Table 6 | Descriptive statistics parameters for the area of organisational skills

\begin{tabular}{|c|c|c|c|c|}
\hline \multirow{2}{*}{$\begin{array}{l}\text { Organisation } \\
\text { skills } \\
\text { LS }\end{array}$} & \multicolumn{2}{|c|}{ os } & \multicolumn{2}{|c|}{ sS } \\
\hline & AP & $\mathbf{R P} \%$ & AP & $\mathbf{R P} \%$ \\
\hline 1 & 40 & 25.5 & 25 & 15.7 \\
\hline 2 & 40 & 25.5 & 45 & 29.1 \\
\hline 3 & 36 & 23.1 & 45 & 29.1 \\
\hline 4 & 18 & 12.4 & 32 & 20.6 \\
\hline 5 & 21 & 13.5 & 8 & 5.5 \\
\hline Total & 155 & 100 & 155 & 100 \\
\hline
\end{tabular}

Source: own elaboration

Figure 4 shows RP of individual ranks of the LS for the area of organisational skills.

Figure 4 | Radar chart of RP for LS ranks for the area of organisational skills by OS and SS

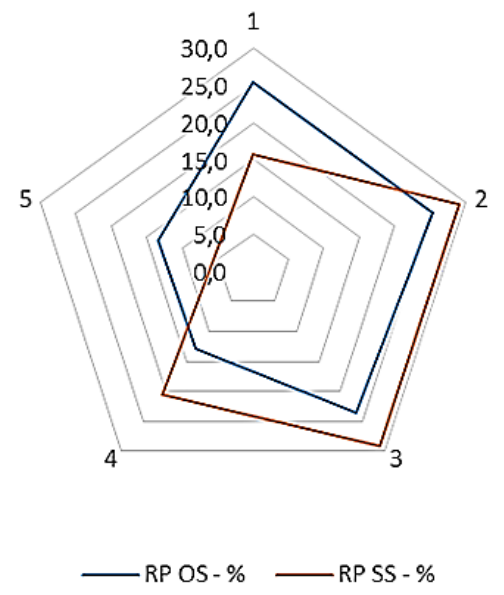

Source: own elaboration

By comparing the graphs OS and SS, it can be concluded that there are no significant differences between the ratings. To confirm the hypothesis about the significance of the 
difference, the Mann-Whitney $U$ test shall be used to test the results. The results of the test for the organisational skills evaluation are shown in Table 7.

Table 7 Results of Mann-Whitney U-test for the area of organisational skills

\begin{tabular}{|c|c|c|c|c|c|c|c|}
\hline Variable & $\begin{array}{l}p<0.05 \\
\text { Sum } \\
\text { of ranks } \\
\text { OSk_OS }\end{array}$ & $\begin{array}{l}\text { Sum } \\
\text { of ranks } \\
\text { OSk_SS }\end{array}$ & $\begin{array}{l}\text { Test } \\
\text { criterion } \\
\text { U - } \\
\text { value }\end{array}$ & $\begin{array}{l}\text { Test } \\
\text { criterion } \\
Z- \\
\text { modified } \\
\text { value }\end{array}$ & $\begin{array}{l}p \text { - } \\
\text { value }\end{array}$ & $\begin{array}{l}\mathrm{N} \text { valid } \\
\text { OSk_OS }\end{array}$ & $\begin{array}{l}N \text { valid } \\
\text { OSk_SS }\end{array}$ \\
\hline $\begin{array}{l}\text { Organisational } \\
\text { skills }\end{array}$ & 2903.00 & 3202.00 & 1363.00 & -0.915 & 0.360 & 155 & 155 \\
\hline
\end{tabular}

Source: own elaboration

Based on the results of testing and the corresponding $p$-value $(p=0.360)$, the null hypothesis was confirmed; there is no statistically significant difference between OS and SS of organisational skills assessment; i.e. reality and expectations are the same. This result points out that graduates predominantly meet the practice requirements for the skills in that area, and there is no need to improve teaching in that area. As the significant statistical difference between the expected and the actual situation was not confirmed, a box plot showing the distribution of respondent ratings is not provided. Median, i.e. the typical value, for the expected organisational skills is 3.0 , which means that practice requires well-developed organisational skills from graduates.

\section{Assessment of competencies in the area of dealing with conflicts}

Table 8 shows the results from questionnaires AP and RP for dealing with conflicts (DC) area. Individual assessments are characterised by the Likert scale (LS) for expected states (OS) and actual states (SS). As we can see, the expected state and the actual state are slightly different.

Table 8 Descriptive statistics parameters for the area of dealing with conflicts

\begin{tabular}{ccccc}
\hline $\begin{array}{l}\text { Dealing with } \\
\text { conflicts }\end{array}$ & OS & \multicolumn{2}{c}{ SS } \\
LS & AP & RP \% & AP & RP \% \\
\hline $\mathbf{1}$ & 26 & 16.4 & 14 & 9.1 \\
$\mathbf{2}$ & 48 & 30.9 & 53 & 34.5 \\
$\mathbf{3}$ & 42 & 27.3 & 48 & 30.9 \\
$\mathbf{4}$ & 22 & 14.5 & 26 & 16.4 \\
$\mathbf{5}$ & 17 & 10.9 & 14 & 9.1 \\
\hline Total & $\mathbf{1 5 5}$ & $\mathbf{1 0 0}$ & $\mathbf{1 5 5}$ & $\mathbf{1 0 0}$ \\
\hline
\end{tabular}

Source: own elaboration

Figure 5 shows the RP of individual ranks of the LS for the area of dealing with conflicts. 


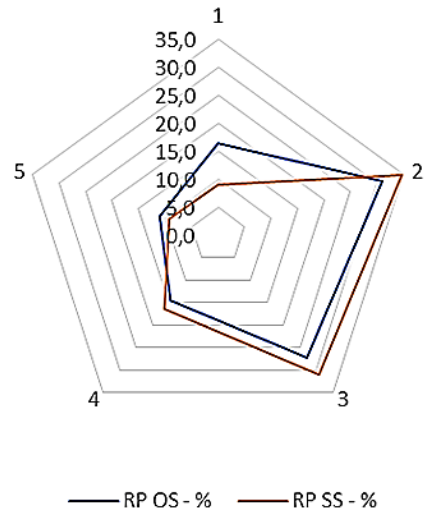

Source: own elaboration

By comparing the graphs for OS and SS, it can be concluded that there are no significant differences between the ratings. This was consequently tested by the Mann-Whitney U-test. The results of the test for the area of dealing with conflicts evaluation are shown in Table 9.

Table 9 | Results of the Mann-Whitney U-test for the area of dealing with conflicts

\begin{tabular}{llllllll} 
Variable & $\begin{array}{l}\text { p }<\mathbf{0 . 0 5} \\
\text { of ranks } \\
\text { DC_OS }\end{array}$ & $\begin{array}{l}\text { Sum } \\
\text { of ranks } \\
\text { DC_SS }\end{array}$ & $\begin{array}{l}\text { Test } \\
\text { criterion } \\
\mathbf{U}-\text { value }\end{array}$ & $\begin{array}{l}\text { Test } \\
\text { criterion } \\
\mathbf{Z}-\end{array}$ & $\begin{array}{l}\text { p- } \\
\text { modified } \\
\text { value }\end{array}$ & $\begin{array}{l}\text { N valid } \\
\text { DC_OS }\end{array}$ & $\begin{array}{l}\text { N valid } \\
\text { DC_SS }\end{array}$ \\
\hline $\begin{array}{l}\text { Dealing } \\
\text { with } \\
\text { conflicts }\end{array}$ & 2975.50 & 3129.50 & 1435.50 & -0.474 & 0.636 & 155 & 155 \\
\hline
\end{tabular}

Source: own elaboration

Based on the results of testing and the corresponding $p$-value $(p=0.636)$, the null hypothesis was confirmed; there is no statistically significant difference between OS and SS of dealing with conflicts assessment; i.e. reality and expectations are the same. This result points out that graduates predominantly meet the practice requirements for the skills in that area, and there is no need to improve teaching in that area. As the significant statistical difference between the expected and the actual situation was not confirmed, a box plot showing the distribution of respondent ratings is not provided. Median, i.e. the typical value, for the expected dealing with conflicts is 3.0 , which means that practice requires well-developed skills from graduates.

\section{Mathematical statistics comparing student versus enterprise}

To test the significance of the difference between students' self-assessment (ST_S) and the enterprises' assessment of graduates from technical universities (COM_E), non-parametric testing by Mann-Whitney U-test was chosen. The results for the areas of soft - skills assessment are shown in Table 10. 
Table 10 | The results of the Mann-Whitney $U$ test for the individual areas of soft skills.

\begin{tabular}{|c|c|c|c|c|c|c|c|}
\hline \multirow[b]{2}{*}{ Variable } & \multicolumn{7}{|l|}{$p<0.05$} \\
\hline & $\begin{array}{l}\text { Sum } \\
\text { of ranks } \\
\text { ST_S }\end{array}$ & $\begin{array}{l}\text { Sum } \\
\text { of ranks } \\
\text { COM_E }\end{array}$ & $\begin{array}{l}\text { Test } \\
\text { criterion } \\
\mathrm{U} \text { - value }\end{array}$ & $\begin{array}{l}\text { Test } \\
\text { criterion } \\
\text { Z- } \\
\text { modified } \\
\text { value }\end{array}$ & $\begin{array}{l}p- \\
\text { value }\end{array}$ & $\begin{array}{l}\mathrm{N} \\
\text { valid } \\
\text { ST_S }\end{array}$ & $\begin{array}{l}\text { N valid } \\
\text { COM_E }\end{array}$ \\
\hline $\begin{array}{l}\text { Creative } \\
\text { thinking }\end{array}$ & 11587.00 & 5991.00 & 2809.00 & -2.561 & 0.0104 & 132 & 155 \\
\hline Teamwork & 11400.50 & 6177.50 & 2622.50 & -3.130 & 0.0017 & 132 & 155 \\
\hline $\begin{array}{l}\text { Organisational } \\
\text { skills }\end{array}$ & 11617.50 & 5960.50 & 2839.50 & -2.445 & 0.0145 & 132 & 155 \\
\hline $\begin{array}{l}\text { Dealing with } \\
\text { conflicts }\end{array}$ & 12632.00 & 4946.00 & 3406.00 & 0.696 & 0.4866 & 132 & 155 \\
\hline
\end{tabular}

Source: own elaboration

Based on the test results and the corresponding $p$-value $(p=0.005)$, we reject the null hypothesis and incline towards the alternative hypothesis that there is a statistically significant difference between the assessment of soft skills by students and companies in the following areas of evaluation:

- Creative thinking,

- Teamwork,

- Organisational skills.

For the other assessed areas (stress resistance and dealing with conflict), testing confirmed the null hypothesis that there is no statistically significant difference between the expected and actual state of soft skills assessment.

Based on the results of testing the significance of the difference by the Mann-Whitney U-test shown in Table 9 were specified areas where testing confirmed a significant statistical difference between students 'versus enterprises 'assessment. The following part brings the graphical illustration of the test of significance using box quartile plots for areas with a confirmed, statistically significant difference.

Figure 6 | Box plot for Creative thinking and Teamwork- students vs enterprises
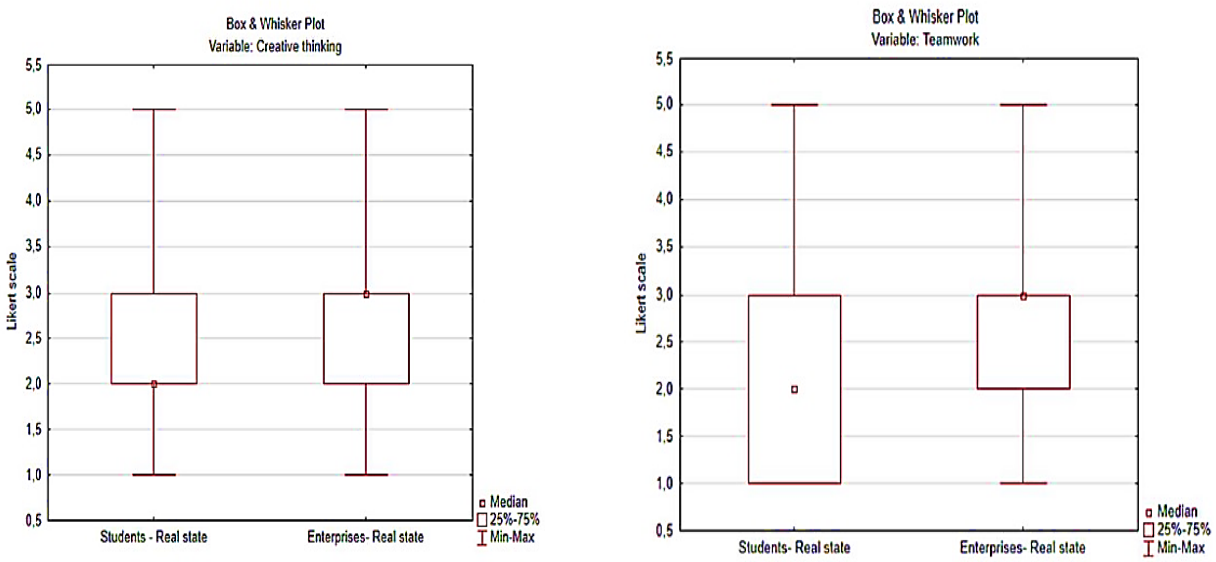

Source: own elaboration 


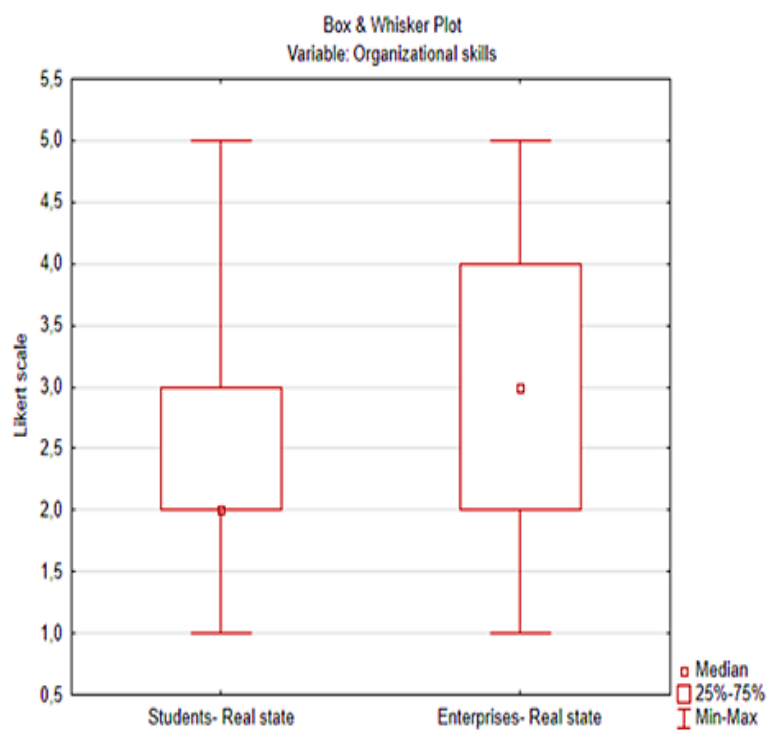

Source: own elaboration

Based on the results presented in Figure 6 and Figure 7, it can be generally summarised that self-assessment of competencies by students is better than the assessment of graduates by enterprises. This means that students assess themselves more positively than the real state assessed by employers in enterprises when assessing the skills of newly hired graduates.

\section{Conclusion}

Increasing demands on the efficiency and effectiveness of business entities are inevitably generating efforts to introduce improved management systems that take into account several rules and documents, thus changing labour market requirements. Employers' demands on candidates' expertise change, with the individual personality of each candidate, are coming to the forefront. These are features that are not usually included in qualification training (Čierna et al., 2020). Today's labour market is characterised by its global nature. This challenge requires the introduction of new competencies for university graduates to work in a domestic or multinational context. What gives one candidate an advantage over others is the added value showed by various professional certificates presenting hard skills or one's interpersonal skills represented by soft skills. In the research, we focused on the analysis of soft skills and summarising the requirements for the soft skills competencies. The results of the questionnaire survey were evaluated by non-parametric testing of significance of the mean value difference by Mann - Whitney $U$ - test. Based on the testing of significance, the hypothesis of the statistical significance of the difference for specific areas of soft skills competencies was confirmed, suggesting that students' competencies in these areas do not reach the level demanded by enterprises. Therefore, it is necessary to improve these skills. Altindag and Kosedagi (2015) indicated the desired soft skill outcomes might be achieved by training emotional intelligence. The soft skills deficit affects business outcomes, including workers' behaviour, safety, engagement, and productivity. Companies are competing based 
on workers' knowledge, which has enhanced the importance of workers' hard and soft skills (Borghans et al., 2014). It is imperative that businesses develop and implement strategies for developing successful soft skills training programs to address the soft skills deficit. Failure to do so has far-reaching implications in terms of negative business outcomes in this highly competitive global work environment. We recommend that a larger study be performed to examine the relationship between the types of strategies for developing and improving emotional skills and the size or type of the organisation. Individuals with soft skills deficits and emotional behaviours could affect business outcomes. As global business competition increases (Bailly and Lene, 2013), it is of paramount importance for businesses to employ individuals who master soft skills and emotionally intelligent managers.

\section{Acknowledgement}

This paper is the partial result of the Project No. 005TU Z-4/2020 under KEGA agency, Slovakia.

\section{References}

Andiliou, A., \& Murphy, P. K. (2010). Examining variations among researchers' and teachers' conceptualisations of creativity: A review and synthesis of contemporary research. Educational Research Review, 5(3), 201-219. https://doi.org/10.1016/j.edurev.2010.07.003.

Altindag, E., \& Kosedagi, Y. (2015). The relationship between emotional intelligence of managers, innovative corporate culture and employee performance. Procedia: Social and Behavioral Sciences, 210, 270-282. https://doi.org/10.1016/jj.sbspro.2015.11.367.

Baer, J., \& Kaufman, J. C. (2019). Assessing creativity with the consensual assessment technique. In I. Lebuda, \& V. Glăveanu (Eds.). The Palgrave handbook of social creativity research. Palgrave studies in creativity and culture. Palgrave Macmillan.

Bailly, F., \& Lene, A. (2013). The personification of the service labour process and the rise of soft skills: A French case study. Employee Relations, 35, 79-97. https://doi.org/10.1108/01425451311279429.

Bereczki, E. O., \& Kárpáti, A. (2018). Teachers' beliefs about creativity and its nurture: A systematic review of the recent research literature. Educational Research Review, 23, 25-56.

Borghans, L., Weel, B., \& Weinberg, B. (2014). People skills and the labor-market outcomes of underrepresented groups. Industrial \& Labor Relations Review, 67, 287-334. https://doi.org/ $10.1177 / 001979391406700202$.

Čierna, H., Sujová, E., \& Bambura, R. (2020). Application of soft-skills competence in practice (practice vs. students). Multidisciplinary Aspects of Production Engineering, 3(1), 537-547

Conti, B., and Kleiner, B. (2003). How to Increase Teamwork in Organisations. Journal of Quality, 5(1), $26-29$.

Dawson, P., \& Guare, R. (2010). Executive skills in children and adolescents: A practical guide to assessment and intervention (2nd ed.). The Guilford Press

De Villiers, R. (2010). The incorporation of soft skills into accounting curricula: preparing accounting graduates for their unpredictable futures. Meditari Accountancy Research, 18, 1-22. https://doi.org//10.1108/10222529201000007.

Eteläpelto, A., \& Lahti, J. (2008). The resources and obstacles of creative collaboration in a long-term learning community. Thinking Skills and Creativity, 3(3), 226-240. https://doi.org//10.1016/j.tsc.2008.09.003. 
Froebel, P., and Marchington, M. (2005). Teamwork Structures and Worker Perception: A Cross National Study in Pharmaceuticals, International Journal of Human Resource Management, 16(2), 256276. https://doi.org/10.1080/0958519042000311435.

Fry, R. (2005). Get organised, 3rd edition. Clifton Park, NY: Thomas Delmar Learning.

Gambill, J. M., Moss, L.A., \& Vescogni, C.D. (2008). The impact of study skill and organisational methods on student achievement. Retrieved from ERIC database. (ED 501312).

Gajda, A., Karwowski, M., \& Beghetto, R. A. (2017). Creativity and academic achievement: A metaanalysis. Journal of Educational Psychology, 109(2), 269-299. https://doi.org/10.1037/edu0000133

Holečková, Y. (2010). Soft Skills: Key Activity 2 Comprehensive Education. Retrieved from: http://www.projektmanazer.cz/kurz/moduly/modul-h.html

Kaufman, J. C., \& Sternberg, R. J. (2007). Creativity. Change the Magazine of Higher Learning, 39(4), $55-60$.

Levasseur, R. E. (2013). People skills: Developing soft skills-A change management perspective. Interfaces, 43, 566-571. https://doi.org/10.1287/inte.2013.0703.

Mulika. (2010). The impact of teamwork on employee performance in strategic management and the performance improvement department of Abu Dhabi police. UAE.

Mullet, D. R., Willerson, A., Lamb, K. N., \& Kettler, T. (2016). Examining teacher perceptions of creativity: A systematic review of the literature. Thinking Skills and Creativity, 21, 9-30. https://doi.org/10.1016/j.tsc.2016.05.001.

Murti, A. (2014). Why Soft Skills Matter. IUP Journal of Soft Skills, 8(3), pp. 32-36.

O'Brien, P. S. (2001). Making College Count: A Real World Look at How to Succeed in and After College. Monster Com.

Park, J. Y., Im, I., \& Sung, C. (2017). Is social networking a waste of time? The impact of social network and knowledge characteristics on job performance. Knowledge Management Research and Practice, 15(4), 560-571. https://doi.org/10.1057/s41275-017-0071-9.

Peters-Kühlinger, G. (2007). Communication and other "soft" skills: use your potential, develop your soft skills and become more successful. Grada.

Robles, M. M. (2012). Executive perceptions of the top 10 soft skills needed in today's workplace. Business communication quarterly, 75(4), 453-465.

Runco, M. A., and Jaeger, G. J. (2012). The standard definition of creativity. Creativity Research Journal, 24, 92-96. https://doi.org/10.1080/10400419.2012.650092.

Sarsani, M. R. (2005). Creativity: Definition and approaches. In M. R. Sarsani (Ed.). Creativity in education (pp. 2-3). New Delhi: Sarup and Sons.

Sharma, M. (2009). How Important Are Soft Skills from the Recruiter's Perspective ICFAI. Journal of Soft Skills, 3(2).

Simonton, D. K. (2012). Taking the US patent office criteria seriously: A quantitative three-criterion creativity definition and its implications. Creativity Research Journal, 24, 97-106. https://doi.org/10.1080/10400419.2012.676974.

Sullivan, F. R. (2017). Creativity, technology, and learning: Theory for classroom practice. Routledge.

Tarricone, P., and Luca, J. (2002). Successful teamwork: A Case Study. Edith Cowan University, Perth, Australia.

Vehmaa, A., Karvinen, M., \& Keskinen, M. (2018). Building a More Sustainable Society? A Case Study on the Role of Sustainable Development in the Education and Early Career of Water and Environmental Engineers. Sustainability, 10(8), 2605. https://doi.org/10.3390/su10082605. 
Walsh, C., Chappell, K., \& Craft, A. (2017). A co-creativity theoretical framework to foster and evaluate the presence of wise humanising creativity in virtual learning, environments (VLEs). Thinking Skills and Creativity, 24, 228-241. https://doi.org/10.1016/j.tsc.2017.01.001.

Weiner, B. (2000). Intrapersonal and Interpersonal Theories of Motivation from an Attributional Perspective. Educational Psychology Review, 1-14.

$\mathrm{Wu}, \mathrm{T} . \mathrm{T} .$, \& Wu, Y. T. (2020). Applying project-based learning and SCAMPER teaching strategies in engineering education to explore the influence of creativity on cognition, personal motivation, and personality traits. Thinking Skills and Creativity, 35, 100631.

The research paper passed the review process. | Received: October 14, 2020; Revised: December 3, 2020; Accepted: December 28, 2020; Pre-published online: April 19, 2021; Published in the regular issue: December 6, 2021. 